\title{
The Use of Vocabulary Learning Strategies among Form 6 Students in a Malaysian Private School
}

Ife Sam A/P Sasidaran, Shangkari A/P Jaikrishnan, Siti Nurzahidah Binti Ahmad Dawawi, Hanis Arini Binti Mohamad Sayuti, Mohd Asrafeel Bin Bakar@Abu Bakar, Agnes Teh Guat Ann, Harwati Hashim

To Link this Article: http://dx.doi.org/10.6007/IJARBSS/v11-i7/10039 DOI:10.6007/IJARBSS/v11-i7/10039

Received: 10 May 2021, Revised: 12 June 2021, Accepted: 27 June 2021

Published Online: 09 July 2021

In-Text Citation: (Sasidaran et al., 2021)

To Cite this Article: Sasidaran, I. S. A., Jaikrishnan, S. A., Dawawi, S. N. B. A., Hanis Arini Binti Mohamad Sayuti, M. A. B. B. B., Ann, A. T. G., \& Hashim, H. (2021). The Use of Vocabulary Learning Strategies among Form 6 Students in a Malaysian Private School. International Journal of Academic Research in Business and Social Science, 11(7), 303-314.

\section{Copyright: (c) 2021 The Author(s)}

Published by Human Resource Management Academic Research Society (www.hrmars.com)

This article is published under the Creative Commons Attribution (CC BY 4.0) license. Anyone may reproduce, distribute, translate and create derivative works of this article (for both commercial and non-commercial purposes), subject to full attribution to the original publication and authors. The full terms of this license may be seen at: http://creativecommons.org/licences/by/4.0/legalcode

Vol. 11, No. 7, 2021, Pg. 303 - 314 


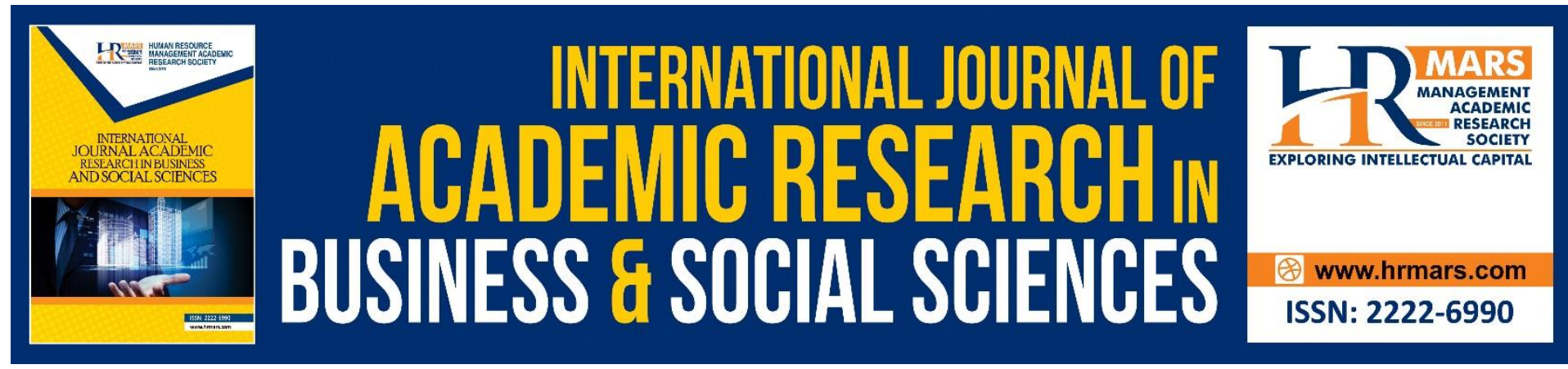

\section{The Use of Vocabulary Learning Strategies among Form 6 Students in a Malaysian Private School}

\section{Ife Sam A/P Sasidaran ${ }^{1,7}$, Shangkari A/P Jaikrishnan ${ }^{2,7}$, Siti} Nurzahidah Binti Ahmad Dawawi ${ }^{3,7}$, Hanis Arini Binti Mohamad Sayuti ${ }^{4,7}$, Mohd Asrafeel Bin Bakar@Abu Bakar"5,7, Agnes Teh Guat Ann ${ }^{6,7}$, Harwati Hashim ${ }^{7}$

${ }^{1}$ Sekolah Jenis Kebangsaan Cina Khiak Yew, 76460 Alor Gajah, Melaka, Malaysia, ${ }^{2}$ SM Pin Hwa, 41400 Klang, Selangor, Malaysia, 3'Sekolah Kebangsaan Kepong, 52100 Kepong, Selangor, Malaysia, ${ }^{4}$ Sekolah Kebangsaan Legeh, 17700 Ayer Lanas Jeli, Kelantan, Malaysia, ${ }^{5}$ North Borneo University College, 88400 Kota Kinabalu, Sabah, Malaysia, ${ }^{6}$ SJKC Ying Wah, 42200 Klang, Selangor, Malaysia, ${ }^{7}$ Faculty of Education, Universiti Kebangsaan Malaysia, 43600 Bangi, Malaysia

\section{Abstract}

There are varieties of vocabulary learning strategies that can be implemented by all students. According to various past studies, vocabulary learning strategy is one of the learning methods that benefit pupils' learning style and method inside and outside of the classroom. The findings of past studies indicate that vocabulary learning strategies improve students' understanding in mastering a topic and this is also applied with learning vocabulary. Thus, the aim of this study is to investigate the vocabulary learning strategies employed by 50 Form 6 students in Malaysian private schools. This study was carried out at a suburban Chinese independent secondary school which is based in Klang, Selangor. The researchers utilized a quantitative approach by using surveys as a data collection tool. The findings of this study indicated that most of the students responded neutrally due to their limited knowledge of vocabulary learning strategies. Nonetheless, the most preferred vocabulary learning strategies were guessing and dictionary strategies whereas the least preferred strategy was using word lists which fall under rehearsal strategy. Therefore, it is hoped that the findings of this study would benefit the English teachers to identify the most preferred vocabulary learning strategy implemented by most of the students in their learning and reflects their implication on teaching strategies.

Keywords: Vocabulary Learning Strategy, Vocabulary Acquisition, Form 6 Students.

\section{Introduction}

Students use a variety of learning strategies depending on their plan and suitability in order to tackle the lesson or subject that they want to master, this also includes learning a language. Learning vocabulary is one of the most important aspects of learning a language, hence, the 
more vocabulary we know, the better we are able to comprehend what we read and hear. Regardless of the usefulness of vocabulary and numerous methods for learning it, the students need to come up with the most effective strategies for them to equip them with vocabulary knowledge. According to Munawaroh (2017), learning won't be compelling without a learning strategy.

When it comes to deciding which learning strategies are the most compelling, there will be no specific decision for this as different students will use different kinds of learning strategies that are compatible and suit with their learning style. On the other hand, some of the students might be having difficulties in finding the right method to be used in their learning. Thus, there are some learning strategies suggested that can be used by the students as a reference and a guidance for them in searching which learning strategies suit them the best. As stated by Mariani (2002), there are no intrinsically "good" strategies because people need to discover their own. Apart from this, although there are numerous numbers of strategies that can be used by the students in their learning, they need to choose or apply some of the strategies in order to discover which learning strategy would be suitable for their learning style and for the topic or subject that they want to master. This is because, applying learning strategies will not only help the students to learn systematically but it also contributes in helping the student's cognitive and affective process in their learning. According to Kafadar and Tay (2014), learning strategies can be described as the whole of the performed activities of the learner to give meaning to information in cognitive and affective processes.

Learning strategies may be used to a broad range of contexts. The purpose of it is not only to be used to learn a subject, but also it can be used in learning a language. Learning vocabulary is one of these objectives. The importance and the value of equipping vocabulary knowledge among the students play an important role in order for them to learn and master a language. This is because vocabulary is one of the roots or elements in a language that need to be considered especially in daily learning as every day, the students will learn a new vocabulary item and it will be challenging for them as they need to understand and store new information that they had learnt throughout the lesson. As stated by Laufer and Nation (2013), earning vocabulary items plays a vital role in all language skills (i.e., listening, speaking, reading, and writing). Therefore, equipping vocabulary would be a great assist for the students not only in learning the target language, but also their development in language skills.

In addition, in order to learn and equip vocabulary knowledge, the students need to apply some of the vocabulary learning strategies (VLS) in their learning so that it will be easier and systematic for them to learn the vocabulary with a proper guidance that is compelling with their learning styles. According to Heng (2011), the vocabulary learning strategies generally involve cognitive strategies, metacognitive strategies and social strategies. These three elements play a vital role where each of these factors contribute as the main element to be implemented in the vocabulary learning strategies in order to accommodate the student's learning style and their suitability in learning the target language hence this will also to overcome the factor of insufficient vocabulary knowledge among the students. Additionally, different students will face different difficulties in applying the VLS as the factors of learning styles, genders and their proficiency will affect the duration of their learning process. Some may even find it difficult to employ the right strategies as they may not have enough information about the strategies (Mahalingam \& Yunus, 2016). They may not be 
frequent users of strategies as good language learners and so, they may require more guidance to regulate their learning.

Even though the students have their own way in tackling and mastering a certain topic or subject, somehow, they will use and apply some of the learning strategies throughout their learning session to ease them to be more systematic by following strategies that they have chosen according to the suitability of their learning style. As stated by Azmimurad and Osman (2019), different strategies work differently on different individuals, thus the students will decide and choose which VLS suit them the most. Therefore, the main purpose of this study is to identify the vocabulary learning strategies utilized by the students in learning a language element which is vocabulary. Other related past studies on the vocabulary learning strategies are also included.

The research question for this study is:

- What are the vocabulary learning strategies employed by the senior three students in Malaysian secondary school?

\section{Literature Review}

\section{Language Learning Strategies (LLS)}

Every learning process requires a strategy that needs to be adapted to attain the main objectives of learning. Hardan (2013) mentioned one of the important things in the process of learning is "what" to use for learning and "how" to use. Hence, human beings are involved with different types of strategies while learning a language. According to the earlier researchers, Rubin (1975) and Stern (1975) learning strategies are defined as devices or techniques applied by learners to acquire the knowledge and information. O'Malley, Chamot, Stewner-Manzares, Kupper and Russon (1985) and Politzer (1983) propounded that LLS are forms of skills such as listening, speaking, reading, writing and thinking implemented in obtaining information or content for language learning. To get to the point, LLS are specific thoughts, behaviours and methods that learners utilize to develop new and enhance existing knowledge in the learning of language. Since the study of LLS has become well known in the field of education, since then various studies have been conducted on the topic discussing different types of LLS applied by the learners. Kamalizad and Samuel (2018) and Amir (2018) agreed that learners that employed a variety of LLS are more likely to succeed in learning the language more effectively.

Apart from that, a study by Jayanthi and Munir (2016); Ong et al (2018) suggested that external factors such as gender, age, motivation, self-confidence, learning activities, cultural backgrounds and academic performance play a major role in influencing student's application of LLS. The factors mentioned can determine a learner's choice of LLS in acquiring the targeted language as different people have different abilities and approaches. Generalizing one strategy is for all is quite unfair for the learners as the factors mentioned should be taken into account. Acknowledging the type of learner and how they feel about learning something can help the education to steer the teaching approach in accordance with the external factors involved. To support this statement, Noor (2000) stated that it is essential for the teacher to understand their learners in terms of behaviors, expectation and preferred ways of learning so that a proper method can be applied in teaching the language. As for language proficiency and selection of LLS, researchers have also proven that learners who are skilled speakers of the language are inclined to embrace a variety of LLS as compared to the low proficient learners (Fatin \& Parilah, 2017; Green \& Oxford, 1995). O'Malley and Chammot (1990) stated in order for the learners to acquire the language better, the need to identify those unique 
characteristics of the effective learners is vital as this effort is to discover the differences with a view to improve the shortcomings of the less successful learners. In a nutshell, studies in language learning aim at training the low-proficiency learners by using the techniques of the advanced learners to improve the skill in language.

\section{Vocabulary Learning Strategies (VLS)}

Oxford Learners Dictionary (2021) defines vocabulary as "all the words that a person knows or uses, all the words in a particular language, the words that people use when they are talking about a particular subject or a list of words with their meanings especially in a book for learning a foreign language". As stated by Putra (2020), vocabulary knowledge is considered as the most important factor in language proficiency and the more vocabulary the learners have, the better they become in using the four skills of a language. The vocabulary owned by the learners sets the borderline of their development in language learning and shows the size of the limitation of using the language in the learners' daily life. Thus, it is evident that vocabulary has an important role in bridging the communication between people in a language. Through numerous studies in identifying problems in learning a language, lack of vocabulary knowledge is one of the obstacles for learners to overcome. Thus, it is important to consider the learners' vocabulary development as an important aspect in language development.

Karadağ (2016) as cited in Melanlioğlu (2020) stated that one of the goals to develop vocabulary practice is to pass on the abilities and routine of learning vocabulary skill to learners since it is unfeasible for the learners to learn and the teachers to ground all the vocabulary in a language during the lesson practice. Good language learners should work independently to gain more words of a language so that they gain the ability to experience coping with the new words as an effort to improve their vocabulary in a language. Thus, it is necessary to inculcate the skills and knowledge in vocabulary learning to raise their awareness towards the vocabulary learning process. One of the ways to facilitate vocabulary learning is through Vocabulary Learning Strategies (VLS) which is actually a component of the Language Learning Strategies (LLS) (Mokhtar et al., 2017). As stated by Melanlioğlu (2020), VLS can be described as the learners are taking over of and managing the process of vocabulary development. In order to motivate the learners to use VLS, good language learners must have the desire to express themselves in the target language. Learning strategies allow the learners to create a self-supporting learning environment and teach them to take responsibility for their individual learning activities, the same also pertaining to VLS. VLS has attracted increasing attention in past years due to its importance in language learning. Due to the increasing attention, many researchers attempt to develop a taxonomy of VLS.

Gu \& Johnson (1996) categorise VLS into four classes namely metacognitive, cognitive, memory and activation. Metacognitive strategies involve the learners determining the words that enable them to recognize the language and decide the suitable ways or skills to learn these vocabs. Cognition strategies are by using dictionaries, guessing and taking notes. Through guessing, the learners are expected to use their prior knowledge to act towards the chosen language. Memory strategies aim to pass on the new vocabulary in distinction from momentary memory to durable memory by taking into account both manner of speaking and connotation. It is essential and compulsory to create lists of words, focus on speech production, using optical and aural cues and do revision. Activation strategies are where the grasped word is utilised by the learners in different conditions. Schmitt and Schmitt (2020) categorise VLS into two designs. The design that is functional for the beginning or new 
discovery of a word's meaning and design that is practical for recollection once the word has been presented. In the first design which is the determination design, the learners discover the definition of new vocabulary through both predicting and gaining help. The second design known as consolidation design includes cognitive, metacognitive and memory strategies as introduced in Gu and Johnson (1996). Vocabulary learning strategies are classified with their key strategies. Bitchener (2007) categorised them as planning, resourcing and processing. During the planning stage, the learners have the autonomy to decide on the ways to focus on vocabulary. Resource strategies demand the need to gain data about the words by using the indications given in the conditions, materials for resourcing such as dictionaries and may associate them to the elements of their mother tongue. For the processing strategies, Bitchener (2001) refers to raising the learners' consciousness of the vocabulary learning operations and building up the vocabulary in the chosen language by using various skills in VLS.

\section{Past Studies on VLS}

There are a number of studies on Vocabulary Learning Strategies (VLS) over the past years. In 2010, a study with 360 students was conducted by Ahmad Azman Mokhtar et al. on "Vocabulary Learning Strategies of Adult ESL Learners". Gu and Johnson's (1996) questionnaire was used to gather the data. The results showed that guessing and dictionary strategies are the most used strategies while metacognitive regulation, note-taking, rehearsal, encoding and activation strategies were least used.

In 2017, Dwita Laksmita Rachmawati conducted a qualitative study on "Vocabulary learning strategies used by first year EFL students". The results were based on Schmitt's (2000) VLS categories. For the strategies for discovering meaning, using an English-Indonesia dictionary, guessing meaning from context, and analysing pictures or gestures were highly preferred. The less favourable from discovering meaning were checking for first language cognates, analysing affixes and roots, and analysing part of speech. In terms of strategies for consolidating meaning, most students chose studying and practicing meaning within a group, imaging word form, and imaging words' meaning.

In 2015, a study conducted by Julie Bytheway on "A Taxonomy of Vocabulary Learning Strategies Used in Massively Multiplayer Online Role-playing Games", introduces a new perspective to vocabulary learning. The case study showed 15 vocabulary learning strategies while playing online games. The strategies are noticing frequency, recognizing knowledge gaps, selecting words for attention, equating images and actions to words, giving and receiving explanations and feedback, observing players, using words to learn words, reading in-game information, and using Google to learn vocabulary autonomously.

Based on the studies above, VLS is appropriate to be implemented in more schools with different settings as the findings from previous studies have shown the improvement and positive impact of the learner's vocabulary development.

\section{Methodology}

In this study, a survey research design was used to obtain data from a suburban private secondary school in Klang, Selangor. 50 Senior Three (equivalent to Form Six in national school) were randomly selected as the research participants. This study utilized a questionnaire as an instrument to investigate the vocabulary learning strategies employed by the Form Six students. The questionnaire, which contained 52 items, was constructed in a 
Google form and was sent to the participants via WhatsApp by one of the researchers working in the said school. Data from this questionnaire was analyzed using a descriptive approach.

\section{Vocabulary Learning Questionnaire}

The questionnaire used in this current study was an adapted version of Vocabulary Learning Questionnaire (VLQ) Version 6.4, updated and validated by Gu (2018). The VLQ was first published in Gu and Johnson (1996) to be used among Chinese English as a Foreign Language (EFL) learners at tertiary level. The questionnaire was designed in English, but was later translated to Chinese and only the translated version was used as well as validated. Not only that, the original version had 108 items which was deemed too long by other researchers who adapted the questionnaire for learners in other parts of the world. Then, in 2003, another version (VLQ 5) was published, but again, only the translated Chinese version was validated and used (Gu \& Hu 2003). The number of items was reduced to 90, yet it was considered to be too long. Thus, in 2018, an updated version of VLQ (Version 6.4), that too in English, was validated and the number of items was reduced to 62 items only, while maintaining similar content coverage (Gu, 2018).

The VLQ was designed to find out learners' beliefs about vocabulary learning and their self-reported vocabulary learning strategies. Moreover, the VLQ Version 6.4 made use of a 7point Likert scale and an online slider-bar with 0 at one end and 100 at the other end. However, in the adapted version of VLQ Version 6.4 used in this current study, only the items designed to elicit learners' self-reported vocabulary learning strategies were included, and a 3-point Likert scale (Untrue of me, Neutral and True of me) was used to help obtain more accurate responses from the participants and also to prevent them from getting confused.

\section{Reliability and Validity}

The VLQ Version 6.4 was successfully validated for its content (vocabulary, grammar and sentence structure) and construct (factor structure and factor correlations) using various methods and tools. Furthermore, Cronbach's alpha for each strategy was obtained to check the internal consistency reliability of the questionnaire. As a result, the VLQ Version 6.4 was found to be a largely reliable instrument.

\section{Findings and Discussion}

The data was analysed using a descriptive approach through frequency count. Findings of this research were presented in Table 1 as shown below to identify the vocabulary learning strategies employed by the senior three students in a Malaysian Chinese independent school. Discussion of strategies that were most and least preferred by students would be further explained in this section. 
Table 1. Strategies in Learning Vocabulary among Form 6 Students

\begin{tabular}{|c|c|c|c|c|}
\hline \multirow[b]{2}{*}{ No. } & \multirow[b]{2}{*}{ Categories and strategies } & \multicolumn{3}{|c|}{ Percentage $(n=50)$} \\
\hline & & Untrue to me (\%) & Neutral (\%) & True to me (\%) \\
\hline \multirow[t]{3}{*}{1.} & Metacognitive strategies & & & \\
\hline & Selective attention & 9 & 48 & 43 \\
\hline & Self-initiation & 30.5 & 44 & 25.5 \\
\hline \multirow[t]{2}{*}{2.} & Inferencing & & & \\
\hline & Guessing strategies & 5 & 42 & 53 \\
\hline \multirow[t]{2}{*}{3.} & Using dictionaries & & & \\
\hline & Dictionary strategies & 7 & 43 & 50 \\
\hline \multirow[t]{3}{*}{4.} & Taking notes & & & \\
\hline & $\begin{array}{l}\text { Choosing which word to put into } \\
\text { notebook }\end{array}$ & 22 & 35 & 43 \\
\hline & $\begin{array}{l}\text { Deciding what information goes } \\
\text { into notes }\end{array}$ & 19 & 40 & 41 \\
\hline \multirow[t]{4}{*}{5.} & Rehearsal & & & \\
\hline & Use of word lists & 46 & 35 & 19 \\
\hline & Oral repetition & 14 & 41 & 45 \\
\hline & Visual repetition & 27 & 43 & 30 \\
\hline \multirow[t]{5}{*}{6.} & Encoding & & & \\
\hline & Visual encoding & 25 & 45 & 30 \\
\hline & Auditory encoding & 29 & 41 & 30 \\
\hline & Use of word structure & 24 & 48 & 28 \\
\hline & Contextual encoding & 20 & 52 & 28 \\
\hline \multirow[t]{2}{*}{7.} & Activation & & & \\
\hline & Activation strategies & 16 & 49 & 35 \\
\hline
\end{tabular}

Based on the above table, it was found that neutral responses from the students encompassed $35 \%$ to $52 \%$, which was deliberately high. Therefore, it could be deduced that many of the students were unsure of the vocabulary strategies that they employed as well as having limited knowledge on vocabulary learning strategies. This is in congruent with findings from Mokhtar et al (2017) as the respondents in the study had also utilized limited strategies in learning vocabulary. According to $\mathrm{Gu}$ and Johnson (1996), these students would be classified as passive strategy users as they showed inadequacy in the usage of multiple strategies while acquiring the knowledge of vocabulary. Thus, making them poor learners since good learners would always employ a range of techniques and strategies, study and practice the target words and be aware of the language's linguistic components (Sanaaoi, 1995). Therefore, it is important to make students understand the various types of vocabulary learning strategies so that they can apply them concurrently for an effective learning process to take place. 
Although many students were neutral about the vocabulary strategies employed, it was found that there were two strategies which were most used by the Senior Three students. More than half of the students (53\%) agreed that they used guessing strategies which derived from an inference approach to learn vocabulary. In this strategy, many of them agreed upon the method of applying common sense, background knowledge, knowledge of the word and contextual clues when guessing the meaning of a word. A study from Ahmad et al. (2018) has proven that guessing strategies through contextual clues serve as an effective cognitive strategy in learning vocabulary. The participants from the study were found to be selfsufficient in their guessing of word meaning by making deliberate choices, as well as having little regard for the teacher while attempting to apply the techniques taught.

Another strategy which was widely used by the students was dictionary strategies. Half of the students (50\%) have employed dictionary strategies in learning vocabulary. Among the various items in dictionary strategies, many of them agreed upon using dictionaries to search for unfamiliar words, words that are important to the understanding of a sentence or paragraph and words which are related similarly or differently rather than wanting to have deeper knowledge and know the usage of the vocabularies. This result is in par with many of the past studies on students' vocabulary learning strategies in Malaysia context (Asgari \& Mustapha, 2011; Mokhtar et al., 2017). It is believed that in Malaysian classrooms, the teachers would always encourage and train the students to refer to the dictionary to search for unfamiliar words, thus this strategy would often be employed by most of the students. Goundar (2019) also stated that the dictionary is a powerful tool in enhancing students' vocabulary repertoire as it allows them to not only check the meaning of the words but also learn the pronunciation and usage of the words.

On the other hand, the least strategy employed was the use of word lists which derived from the rehearsal approach in learning vocabulary. It is shown that $46 \%$ of the students agreed that was the least favourite strategy among them. The students are not in favour of learning vocabulary using word lists such as making vocabulary cards, going through the vocabulary lists and making regular reviews of new words they have memorised. Instead of that, they would prefer more on oral repetition in this rehearsal approach. The data portrayed that $45 \%$ of them agreed on the strategy by saying aloud, repeating the sound and pronunciation of new words to remember the vocabulary. The findings are parallel with the studies by Samat and Hashim (2019), where the greatest number of pupils preferred not to write the new word on a card. Meanwhile, more than half of them chose to say the words many times until they could say it correctly. Pupils claimed that writing was a tedious process which took a lot of time and effort, thus resulting in them avoiding using this strategy.

Apart from that, the encoding strategies are the most neutral responses among all the strategies. Gu and Johnson (1996) listed that encoding strategies encompass such strategies as association, imagery, visual, auditory, semantic, and contextual encoding as well as word structure (such as analyzing a word in terms of prefixes, stems, and suffixes). In this strategy, many students opted for being neutral especially contextual encoding with $52 \%$ of them. The reason being might be this learning strategy was less incorporated with their learning task. Wenden (1987) as cited in Ranalli (2003) stated that learning strategy practice should be integrated with regular language learning tasks, thus students could see it as relevant and not time taken away from normal learning. Therefore, it is vital that students should practise a wide range of vocabulary learning strategies and be trained in strategies they lack. 


\section{Conclusion}

This study has explored and identified students' viewpoints on the most compelling vocabulary learning strategies that suit their learning method to be used particularly in the classroom. It has shown that there are a variety of strategies implemented by the students in learning and understanding vocabulary. Besides, in view of the findings of this study, it has also identified the most common sufficient vocabulary learning strategies preferred by some groups of the students in learning and tackling the topic or lesson of vocabulary. As in general, it has shown that most of the students preferred to implement any vocabulary learning strategy that suits their learning style in order to understand better about vocabulary instead of having no strategy to be employed in their learning.

Numerous studies have been conducted on vocabulary learning strategies which have identified how learners of a language employ the said strategies, with some degree of similarities and differences. Similarly, the findings of this study are parallel to the findings of previous studies, thus further reiterating the studies on vocabulary learning strategies. As such, this could provide a guide to all learners of different levels and institutions as they could identify strategies that suit their classroom context and help them in enhancing their learning process, particularly in understanding the lesson for vocabulary. Moreover, some of the students might struggle in finding the suitable strategy to be used in their learning and they might not know how to learn vocabulary in the first place. Thus, the findings of this study could be used to assist the language teachers in identifying vocabulary learning strategies in their own classroom in order to enhance the students' understanding of vocabulary lessons. As stated by Kistner et al. (2015), teachers are required to provide students with understanding about how to learn in their classes. Therefore, this study could benefit both language learners and teachers in learning more about the use of vocabulary learning strategies.

Furthermore, it is also hoped that this study could change the students' perception and awareness in the use of vocabulary learning strategies in their lessons. With profound perception and awareness, students are expected to obtain a better understanding of the context of a lesson, and also be confident in applying vocabulary learning strategies in their classroom. Therefore, it is recommended that further research regarding vocabulary learning strategies should be carried out in order to identify the strategies that might be effective and most preferred used by the students in learning vocabulary so that it could be used as a reference for the educators and learners of different levels and institutions.

\section{References}

Ahmad, S. N., Muhammad, A. M., \& Kasim, A. M. (2018). Contextual Clues Vocabulary Strategies Choice among Business Management Students. English Language Teaching, 11(4), 107-116.

Amir, M. (2018). Language learning strategies used by junior high school EFL learners. Language and Language Teaching Journal, 21(1), 94-103. https://doi.org/doi.org/10.24071/llt.2018.210110

Asgari, A., \& Mustapha, G. (2011). The Type of Vocabulary Learning Strategies Used by ESL Students in University Putra Malaysia. Canadian Center of Science and Education, 4. https://doi.org/10.5539/elt.v4n2p84

Azmimurad, A. M., \& Osman, N. (2019). Vocabulary Learning Strategies: Learning Engineering Terminology among Engineering Majors for Industry 4.0 Readiness. Universal Journal of Educational Research, 7(12A), 75-84. 
Bitchener, J. (2007). ISP Nation, learning vocabulary in another language. Australian Review of Applied Linguistics, 30(1), 10-1.

Bytheway, J. (2015). A taxonomy of vocabulary learning strategies used in massively multiplayer online role-playing games. Calico Journal, 32(3), 508-527.

Fatin, R. A. H., \& Parilah, M. S. (2017). The Language Learning Strategies (LLS) Used by Successful English Language Learners (SELL) of Primary Students in Labuan. In the International Conference on Global Education - Global Education, CommonWealth, and Cultural Diversity (pp. 2674-2684). Padang, Indonesia: Ekasakti University, Indonesia.

Goundar, P. R. (2019). Vocabulary Learning Strategies (VLSs) Employed by Learners of English as a Foreign Language (EFL). English Language Teaching, 12(5), 177-189.

Green, J. M., \& Oxford, R. L. (1995). A Closer Look at Learning Strategies, L2 Proficiency and Gender. TESOL Quarterly, 29(2), 261-296.

Gu, Y., \& Johnson, R. K. (1996). Vocabulary learning strategies and language learning outcomes. Language Learning, 46 (4), $643-679$.

Gu, Y., \& Hu, G. (2003). Cihui xuexi celue, cihuiliang yu yingyu chengji de bianhua [Vocabulary learning strategies, vocabulary size, and English proficiency: Focusing on change]. In Yingyu xuexi celue shizheng yanjiu [Empirical research on language learning strategies] (pp. 388-409). Shaanxi Normal University Press.

Gu, P. Y. (2018). Validation of an online questionnaire of vocabulary learning strategies for ESL learners. Studies in Second Language Learning and Teaching, 8(2), 325-350.

Hardan, A. A. (2013). A language learning strategies: A general overview. Procedia - Social and Behavioral Sciences, $106,1712-1726$.

Heng, K. (2011). Effective vocabulary learning strategies: Perspectives from Cambodian students and teachers. Doctoral dissertation, Master's thesis, Royal University of Phnom Penh, 3-4. https://doi.org/10.13140/RG.2.2.17395.17445.

Jayanthi, M., \& Munir, S. (2016). Learning Styles, Language Learning Strategies and Fields of Study among ESL Learners. Malaysian Journal of ELT Research, 12(1), 1-19. https://journals.melta.org.my/index.php/majer/article/viewFile/22/5

Kafadar, T., \& Tay, B. (2014). Learning Strategies and Learning Styles Used by Students in Social Studies. International Journal of Academic Research, 6(2).

Kamalizad, J., \& Samuel, M. (2018). Cross Context Role of Language Proficiency in Learners' Use of Language Learning Strategies. MOJES: Malaysian Online Journal of Educational Sciences, 3(1), 1-13. https://mojes.um.edu.my/article/view/12676

Kistner, S., Rakoczy, K., Otto, B., Klieme, E., \& Büttner, G. (2015). Teaching learning strategies. The role of instructional context and teacher beliefs. Journal for Educational Research Online, 7(1), 176-197.

Laufer, B., \& Nation, I. S. P. (2013). Vocabulary. In The Routledge Handbook of Second Language Acquisition (pp. 181-194). Routledge.

Mahalingam, K., \& Md Yunus, M. (2017). Good language learners and their strategies: An insight. Proceedings of the ICECRS, 1(1), 359-366.

Mariani, L. (2002). Learning strategies, teaching strategies and new curricular demands: A critical view. Perspectives, a Journal of TESOL-Italy, XXIX (2), 45-56.

Melanlioğlu, D. (2020). Scale of vocabulary learning strategies for learners of Turkish as a foreign language: A scale development study. Educational Research and Reviews, 15(6), 312-326.

Mokhtar, A. A., Rawian, R. M., Yahaya, M. F., Abdullah, A., \& Mohamed, A. R. (2017). Vocabulary learning strategies of adult ESL learners. The English Teacher, 12. 
Munawaroh, N. (2017). The influence of teaching methods and learning environment to the student's learning achievement of craft and entrepreneurship subjects at vocational high school. International Journal of Environmental \& Science Education, 12(4), 665678.

Noor, Z. (2000). Motivational factors and learners' strategies in the ESL classroom at Universiti Teknologi Malaysia with special reference to computer assisted language learning. Unpublished Thesis.(Doctor of Philosophy).

O’Malley, J. M., Chamot, A. U., Stewner-Manzares, G., Kupper, L., \& Russon, R. P. (1985). Learning strategies used by beginning and intermediate TESL students. Language Learning, 35(1), 21-46.

O'Malley, J. M., \& Chamot, A. U. (1990). Learning strategies in second language acquisition. Cambridge University Press.

Ong, S. S., Lam, D. Y. P., \& Rodrigues, P. D. (2018). Choice of language learning strategies: A case study of proficient and less proficient EFL students in the development of speaking skills of an intensive English programme. BERJAYA Journal of Services \& Management, 10(July), 96-107.

Oxford Learner's Dictionaries. (2021). Vocabulary noun - Definition, pictures, pronunciation and usage. https://www.oxfordlearnersdictionaries.com/definition/english/vocabulary?q=vocabu lary

Politzer, R. (1983). An explanatory study of self-reported language learning behaviours and their relation to achievement. Studies in Second Language Acquisition, 6(1), 54-65.

Putra, I. N. T. D. (2020). Vocabulary learning strategies employed by postgraduate students of Mataram University in academic year 2014/2015. Jo-ELT (Journal of English Language Teaching) Fakultas Pendidikan Bahasa \& Seni Prodi Pendidikan Bahasa Inggris IKIP, 2(2), 74-81.

Rachmawati, D. L. (2018). Vocabulary learning strategies used by first year of EFL students. EnJourMe (English Journal of Merdeka): Culture, Language, and Teaching of English, 2(2), 83-88.

Ranalli, J. M. (2003). The treatment of key vocabulary learning strategies in current ELT coursebooks: repetition, resource use, recording. Unpublished MA thesis. University of Birmingham.[online] available: www. cels. bham. ac. uk/resources/essays/RanalliDiss. pdf (October 21, 2008).

Rubin, J. (1975). What the "Good Language Learner" can Teach Us. TESOL Quarterly, 9, 4151.

Samat, N. A. A., \& Hashim, H. (2019). Language learning strategies employed by successful year 4 primary schools pupils in Shah Alam. In International Journal of Innovative Research and Creative Technology 5(4), 32-36.

Sanaoui, R. (1995). Adults learners' approaches to learning vocabulary in second languages. Modern Language Journal, 79, 15-28.

Schmitt, N. (2000). Vocabulary in language teaching. Cambridge University Press.

Schmitt, N., \& Schmitt, D. (2020). Vocabulary in language teaching. Cambridge University Press.

Stern, H. H. (1975). What can We Learn from Good Language Learners? Canadian Modern Language Review, 31, 304-318. 